\title{
Logistics Distribution Retrieval Support System Using Analytical Hierarchy Process Method
}

\author{
Romualdus Vanadio Yoga S
}

Department of Education Informatics Engineering Program, Sanata Dharma University, Indonesia

\section{Article Info}

Article history:

Received: 02/07/2021

Revised: $16 / 07 / 2021$

Accepted: 06/08/2021

Available online 30/09/2021

\section{Keywords:}

Decision Support System (DSS), Distribution,

Logistics,

AHP method

\begin{abstract}
Logistics Distribution Decision Making Support System is a computerbased information system that can be used to help distributors to distribute logistics in accordance with what is desired. The distributor in this context is the Regional Disaster Management Agency (BPBD) of Magelang Regency Logistics Division. In this system, the distributor will get a result in the form of a decision recommendation that is made based on the distribution's assessment for each prospective beneficiary area. The distribution assessment is determined by the number of criteria used, namely the amount of damage and loss (JKK), category of damage (KK), cost of proposed funds (BuD). In this system, the Analytical Hierarchy Process method is used to determine the comparison of assessments for each candidate area. This method was chosen because it has a hierarchical structure, which is in accordance with the core of the problem in selecting each regional candidate. The distribution of logistics with the Analytic Hierarchy Process method is able to get regional results that are the priority of logistics distribution with an error rate of $17.24 \%$ to $23.78 \%$. The results obtained are the difference between the system and excel scores divided by the excel scores. The results obtained, can be used to help distributors carry out logistics distribution to potential natural disaster areas, and will only help (find the best solution) and not be the main benchmark in logistics distribution.
\end{abstract}

This is an open access article under the CC BY-NC license.

\section{Corresponding Author:}

Romuald Vanadio Yoga S,

Department of Information Engineering Education, University of Sanata Dharma Indonesia,

Email: humas@usd.ac.id

\section{Introduction}

It is well known that natural disasters that have occurred have had significant impacts, ranging from material to fatalities, especially those that have devastated parts of Magelang Regency and its surroundings, causing various polemics after the natural disaster. Especially for the government and people of Magelang Regency, who are in a position not ready to face a disaster. And from this unpreparedness, everything related to rehabilitation after natural disasters has been neglected, which tends to be passive and in a hurry. And this happens for days to weeks so that people become neglected and neglected even though the local government and even the governor have given instructions.

According to the Indonesian disaster-prone index, Magelang Regency is a disaster-prone area with a high level of vulnerability and ranks 34th out of 494 districts in Indonesia.(Isneni, Putranto, \& Trisnawati, 2020). According to the Regional Disaster Management Agency, Magelang Regency is prone to volcanic eruptions, strong winds, floods, landslides and so on.(Isneni et al., 2020). Between 2014 and 2015 there were 255 disasters. 
For every business that has used a computer-based information system in its business activities, it requires a decision-making support system for the distribution of natural disaster logistics based on the area and infrastructure in it and can determine what logistics are needed by the community. This decision support system can also be useful for monitoring distribution over time. This system can also be used as a reference in determining the next steps for areas that are a top priority or not.

In solving problems, the Analytical Hierarchy Process (AHP) method is used to describe a functional hierarchy with the main input being human perception. (Queen, Setiawan, \& Anggraeni, 2013). The existence of this hierarchy makes it possible to break down complex or unstructured problems into sub-problems, then arrange them as a form of hierarchy. Which then recommends the distribution using the manual method so that it takes a lot of time to determine the amount of weight needed in determining the areas that are entitled to logistics.

This system is also not intended to replace the role of the relevant agency in making decisions but only to assist the Logistics Division of the relevant agency in making a decision quickly and accurately, according to the desired criteria or at least close to the desired criteria. Alternative choices are expected to provide a list of references to decision makers before actually making a final decision. This decision support system uses the Analytical Hierarchy Process (AHP) method which is a method of determining the order (priority) in multi-criteria analysis.

With the background of this problem, the author wants to create a decision support system for the distribution of logistics for natural disasters in Magelang Regency. And it is hoped that this system can also be applied in other areas that have experienced these natural disasters.

\section{Method}

\subsection{Data collection technique}

Data collection techniques used are interviews and data selection. The interview was conducted by conducting a question and answer session with the Head of the Logistics Division at BPBD Magelang Regency. Through interviews, researchers can describe the process of proposing funds for logistics distribution to areas affected by natural disasters. The data on the proposed funds that have been obtained are then selected to be used as system testing data.

\subsection{Data}

The data used is data on proposals for aid funds from January to March 2015. The proposed aid funds in question are proposals for funds that must be issued by related parties to be used to replace the damage suffered by residents/villages/sub-districts affected by natural disasters. The data is also used for the basis of testing this program system.

\section{Results and Discussion}

\subsection{Interface Design}

\begin{tabular}{|c|c|c|c|}
\hline \multicolumn{3}{|c|}{ SPPK Pendistribusian Logistik Bencana Alam } & \begin{tabular}{|l|l|} 
& $\square$
\end{tabular} \\
\hline Setup & Input & Hasil & Bantuan \\
\hline \multicolumn{4}{|c|}{ Setup Kriteria } \\
\hline \multicolumn{2}{|c|}{ Setup Daerah } & & \\
\hline \multicolumn{2}{|c|}{ Exit } & & \\
\hline
\end{tabular}

Figure 1. Context Diagram

Based on the number of assessment criteria and the number of regional candidates entered by the user, the system will form matrices that will be used as calculation media. The number of assessment 
criteria and the number of regional candidates will determine the number of matrices formed and the size of these matrices.

Group the priority of regional candidates with respect to each criterion in the columns and enter the priority vector of the criteria above the columns, then multiply each column by the priority of the corresponding criteria to obtain an overall priority vector for the intensity of the criteria of importance for each candidate and then add up each -each of the three candidates to obtain the overall priority of the three candidates.

TABLE 1.

Priority VALUe

\begin{tabular}{|c|c|c|c|c|}
\hline & $\begin{array}{c}\text { Damage Category } \\
(\mathrm{KK}) \\
(0.6650)\end{array}$ & $\begin{array}{c}\text { Total Damage Losses } \\
\text { (JKK) } \\
(0.2310)\end{array}$ & $\begin{array}{l}\text { Proposed Fund Fee (BUD) } \\
\qquad(0.1038)\end{array}$ & $\begin{array}{l}\text { Overall } \\
\text { Priority }\end{array}$ \\
\hline Bandongan & $(0.6650)$ & $(0.2310)$ & $(0.1038)$ & 0.3291 \\
\hline Candimulyo & $(0.6650)$ & $(0.2310)$ & (0.1038) & 0.2562 \\
\hline srumbung & $(0.6650)$ & $(0.2310)$ & (0.1038) & 0.4143 \\
\hline & & & & 1 \\
\hline
\end{tabular}

Based on the results of calculations using the AHP (Analytical Hierarchy Process) method above, the Srumbung Region has the largest overall priority. Because the Srumbung Region has a value of 0.4143 , where later the Srumbung Region will get $41.43 \%$ of the proposed amount of funds later. The Srumbung area has the possibility of being prioritized first as a candidate for distribution area than the Bandongan area or the Candimulyo area.

\subsection{System Implementation}

The design of the logistics distribution decision support system using the Analytical Hierarchy Process method that has been carried out is then implemented into the program. The program is made using the Java programming language and MySQL database.

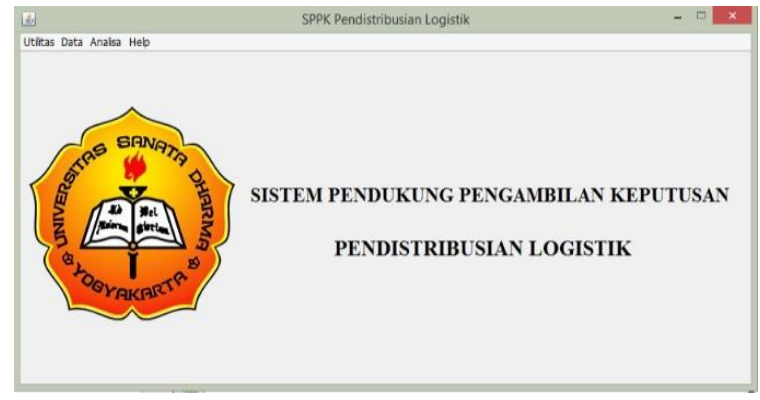

Figure 2.Main Form

The first time the user enters the program, the main page form will be displayed. On the main page form there are various menus and sub-menus. If you want to do calculations, you can press the Analysis menu then the sub-menu from the Analysis menu.

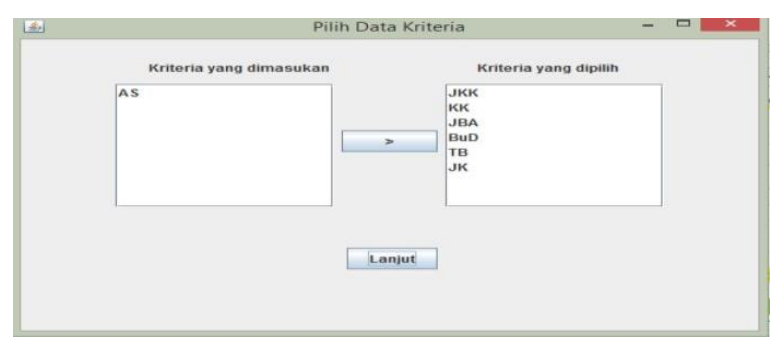

Figure 3.Choose Criteria

The Criteria Select Form is a display that functions to select criteria that have been entered previously, which will be used as a matrix size in the calculation of the criteria. In this form there are 2 buttons, namely $(>)$ and Continue, the $(<)$ button is used to select the entered criteria, while the Continue button is used to continue the calculation. 


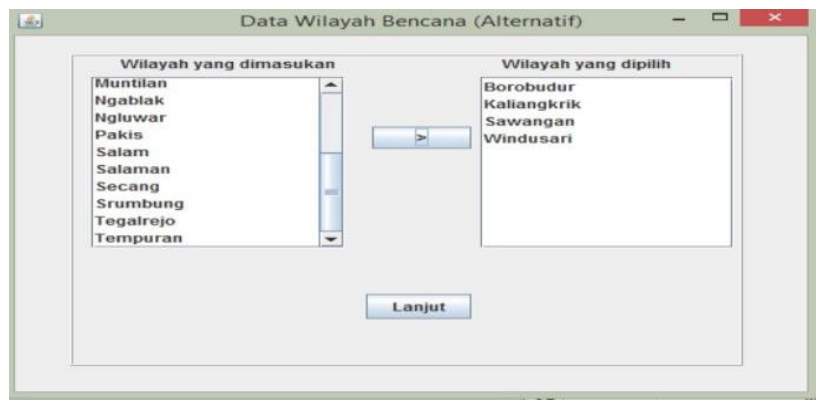

Figure 4.Choose Alternative

The Alternative Select Form is a display that functions to select the disaster area (alternative) that has been previously entered, and will be used as a matrix measure in the calculation of the sub-criteria. In this form there are 2 buttons, namely $(>)$ and Continue, the $(<)$ button is used to select the entered criteria, while the Continue button is used to continue the calculation.

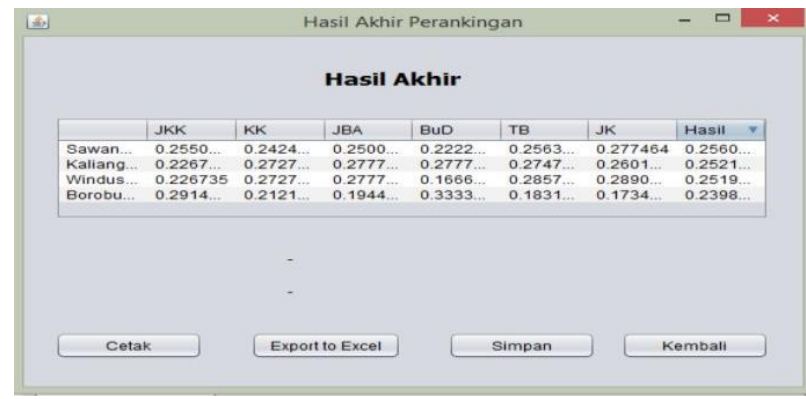

Figure 5.Final Results Ranking

The AHP Ranking Final Result Form serves to display the calculation results from the program. This form displays the selected disaster area data, selected criteria data, and results (priority vector).

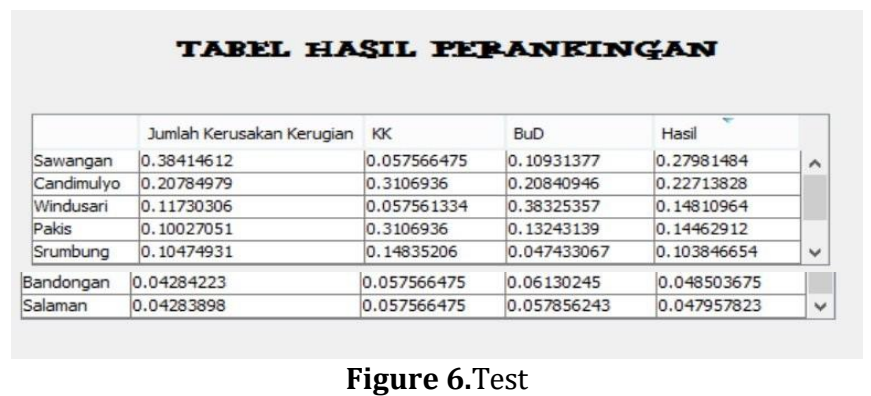

Logistics distribution quickly, accurately and correctly can produce good results, should also be able to adapt to the criteria and areas that are being and or affected by natural disasters. From the many criteria and areas that can be used as calculation assumptions, the Analytical Hierarchy Process method is suitable to be applied in logistics distribution. Because the Analytical Hierarchy Process method requires prioritization and consistency testing of the choices that have been made. What's more, it can be done in complex situations, decision making is not influenced by one factor alone but is multifactorial and includes various levels and various interests.

In the AHP calculation using the system, it can be seen that Sawangan has a value of $(0.27981484)$ among all regions. Which means that Sawangan will get $27.98 \%$ of the total distribution fund later.

\section{Conclusion}

Based on the results of the research and discussion that have been described previously, it can be concluded that; Decision Support System by implementing the Analytical Hierarchy Process method 
can be used as an alternative in determining the distribution of logistics. Logistics distribution using the Analytical Hierarchy Process method is able to get the results of the error rate comparison between excel and system scores from 0.1724039 to 0.2377697 .

\section{Reference}

Isneni, AN, Putranto, TT, \& Trisnawati, D. (2020). Analysis of the Distribution of Landslide Prone Areas Using Remote Sensing and Analytical Hierarchy Process (AHP) in Magelang Regency, Central Java Province. Journal of Geoscience and Technology. https://doi.org/10.14710/jgt.3.3.2020.149-160

Queen, F., Setiawan, H., \& Anggraeni, SK (2013). Design of Human Resources Performance Measurement System with Human Resources Scorecard Approach. Journal of Industrial Engineering.

Keen, Peter GW (1980). Decision support systems: a research perspective. Cambridge, Mass. Center for Information Systems Research, Afred P. Sloan School of Management.

Kusrini. (2011). Decision Support System Concepts and Applications, Andi, Yogyakarta. Saaty, Thomas L. (2000). The Fundamentals of Decision Making and Priority Theory with the Analytic Hierarchy Process, Vol. VI of the AHP Series, , 478 pp., RWS Publ., Pittsburgh.

Turban Ephraim, Jay E. Aronson, Ting-Peng Liang. (2005). Decision Support Systems and Intelligent Systems. Yogyakarta: Andi. 